\title{
Effect of efferent duct ligation, gonadectomy and testosterone replacement on epididymal contractility in the rat
}

\author{
J. Hib and R. O. Ponzio \\ Centro de Investigaciones en Reproducción, Facultad de Medicina, \\ Paraguay 2155-Piso 10, Buenos Aires, Argentina
}

The epididymis is an androgen-sensitive tissue which responds to even minor fluctuations in circulating androgens (Prasad, Rajalakshmi, Gupta \& Karkun, 1973). Epididymal receptors for androgens have been demonstrated (Blaquier, 1971) and male sex hormones are required for epididymal growth and structural and functional maintenance (Benoit, 1926; Risley, 1963; Price \& Ortiz, 1965). Apart from circulating androgen, the epididymis may have access to two other sources of male sex hormones: androgens are present in the testicular fluid entering the epididymis (see Setchell, 1970) and the epididymis might itself be capable of producing androgens (Inano, Machino \& Tamaoki, 1969). Testosterone produced in the testis could pass from the pampiniform plexus to the internal spermatic artery and thence to the caput epididymidis directly or to the cauda epididymidis through anastomoses between branches of the internal spermatic and the vasal arteries (EinerJensen, 1974).

Epididymal contractile activity is known to be dependent upon androgens, but the reports are contradictory. Risley (1959) found that, in orchidectomized rats, spontaneous contractility ceased in the caput and appeared in the cauda epididymidis. This activity was reversed to normal by giving testosterone. Martins, Valle \& Porto (1940) also report that contractions in the more distal regions of the epididymis are inhibited by male sex hormones, but a stimulatory effect of testosterone on the spontaneous contractility of the isolated guinea-pig cauda epididymidis has been suggested (Da Silva e Souza, Gimeno \& Gimeno, 1974). This is surprising because orchidectomy results in a progressive decrease of cholinesterase activity (Risley, 1961) and disappearance of adrenergic terminals from the musculature of the cauda epididymidis (Norberg, Risley \& Ungerstedt, 1967).

In the present study, we examined the androgenic regulation of spontaneous contractility of the rat epididymis in vivo.

\section{Methods}

The 42 5-6-month-old Wistar male rats used were fed and caged under standard conditions apart from female rats. There were 5 treatment groups. Group 1 consisted of 6 untreated control animals. In Groups 2 and 3 ( 6 animals each), both testes were removed; the Group- 2 animals received daily subcutaneous injections of $2 \mathrm{mg}$ testosterone propionate in arachis oil/ $\mathrm{kg}$ body weight. Group 4 comprised 12 animals from which the right testis had been removed; the left epididymis served as a control. Group 5 contained 12 animals in which both testes were present but the right ductuli efferentes were ligated. The contralateral epididymis served as a control for this group.

Anaesthesia was induced by intraperitoneal injection of $30 \mathrm{mg}$ sodium pentobarbitone (Nembutal: Abbott) $/ \mathrm{kg}$. The testis and epididymis were exposed through a midline abdominal incision. In the rat the epididymal vessels arise from the testicular artery at a distance from the testis and allow removal of this organ without injury to the vascular supply of the epididymis. Efferent duct ligations were performed with care to preserve the vascular supply to the testis and epididymis. After ligations or extirpations, the remaining organs were returned to the scrotum and epididymal contractions were registered at various times. For this, the rats were anaesthetized with ethyl carbamate (Urethane: U.S.P.) (15 mg/100 g body weight) and a saline-filled catheter (PE 10 polythylene tubing; i.d. 0.011 in, o.d. 0.024 in: Intramedic) connected to a Sanborn pressure transducer (267 BC) was inserted into the ductus deferens as previously described ( $\mathrm{Hib}, 1976)$. The characteristics of contractile activity evaluated were: tonus changes ( $a \mathrm{~cm} \mathrm{H}_{2} \mathrm{O}$ ), amplitude (in $\mathrm{cm}_{2} \mathrm{O}$ ) and frequency (in contractions/10 min). The data were assessed by Student's $t$ test or by analysis of variance. 


\section{Results and discussion}

Control animals (Group 1). The mean \pm S.E.M. amplitude of spontaneous contractions was $5.4 \pm 0.9 \mathrm{~cm} \mathrm{H}_{2} \mathrm{O}$ and the mean frequency was $11.2 \pm 2.4$ contractions $/ 10 \mathrm{~min}$. Similar values were observed for the left epididymis of the rats in Groups 4 and 5.

Bilateral gonadectomy + testosterone replacement (Group 2). In these animals, epididymal contractility was maintained for the 7 or 14 days of injections after surgery. The mean amplitude was $5.1 \pm 0.8 \mathrm{~cm} \mathrm{H}_{2} \mathrm{O}$ and the mean frequency was $10.5 \pm 2.8$ contractions $/ 10 \mathrm{~min}$. However, at 21 days no contractile activity could be recorded.

Bilateral gonadectomy (Group 3). By 2 days after surgery there was a significant decrease $(P<0.05)$ in the amplitude $\left(2.2 \pm 0.4 \mathrm{~cm} \mathrm{H}_{2} \mathrm{O}\right)$ and frequency $(4.1 \pm 1.7$ contractions $/ 10 \mathrm{~min})$ of the spontaneous epididymal contractions and these ceased completely by 4 days after castration.

Unilateral gonadectomy (Group 4). The effects of this procedure were similar to those of efferent duct ligation. At 7 and 14 days the mean amplitude was $5.9 \pm 0.9 \mathrm{~cm} \mathrm{H}_{2} \mathrm{O}$ and the mean frequency was $10 \cdot 9 \pm 2.9$ contractions $/ 10 \mathrm{~min}$. There was no activity at 21 days.

Efferent duct ligation (Group 5). The contractile activity of the right epididymis (ligated) was not significantly different from that observed for the left epididymis (control) at 7 and 14 days after operation but contractions had ceased by 21 days.

The disappearance of the spontaneous contractions produced after bilateral gonadectomy, and the maintenance of this activity in the animals injected with testosterone, confirm that androgen maintains the activity of the contractile cells in the epididymis. This maintenance is achieved by circulating androgen because the contractility of the epididymis on both sides was normal when unilateral gonadectomy or ligation was performed in the present experiments. These findings also exclude an effect of androgens entering the epididymis in the testicular fluid. The results from bilaterally gonadectomized males show that any androgen which might be synthesized in the epididymis is not able to maintain epididymal motility. On the other hand, the normal activity in the castrated animals injected with testosterone shows that this hormone is able to counteract the absence of the testes. Resko (1970) has shown that plasma testosterone completely disappears within $6 \mathrm{~h}$ of castration and this would explain the significant reduction in the epididymal contractility 2 days after gonadectomy in our experiments.

However, the disappearance of the contractions by 21 days after operation in Groups 2, 3, 4 or 5 indicates that a normal flow of testicular fluid into the epididymis is necessary for the maintenance of the spontaneous motility of the duct. The epididymis is practically free of spermatozoa by 21 days after separation of the testis from the epididymis (Turner \& Johnson, 1971). The physiological integrity of the epididymal canal is known to be dependent not only on the circulating levels of androgens but also on the normal flow of testicular fluid and spermatozoa (Gustafsson, 1966).

Baumgarten, Owman \& Sjöberg (1975) have stated that the male sex hormone influences the development and maturation of the short adrenergic neurones, and involvement of these autonomic nerves with epididymal contractions has been discussed (Hib, 1976). It seems possible that testosterone maintains the contractility of the smooth musculature of the epididymis indirectly by an effect on the short adrenergic nerves. We conclude, therefore, that the presence of circulating testosterone and epididymal fluid are both necessary for normal contractility of the rat epididymis and that the mechanism of control is probably by an influence of this hormone on the short adrenergic neurones.

Supported by Grant 1-1-1-75 from Programa Latinoamericano de Investigaciones en Reproducción Humana (PLAMIRH), provided under the auspices of the Corporacion Centro Regional de Población (Bogatá, Columbia).

\section{References}

Baumgarten, H.G., OWman, C. \& SJöberg, N.O. (1975) Neural mechanisms in male fertility. In Control of
Male Fertility, pp. 26-40. Eds J.J. Sciarra, C. Markland \& J. J. Speidel. Harper and Row, New York. 
BENoIT, J. (1926) Recherches anatomiques, cytologiques et histophysiologiques sur les voies excrétrices du testicule chez les mammifères. Archs Anat. Histol. Embryol. 5, 173-414.

BLAQUIER, J.A.T. (1971) The intracellular binding of androgens in rat epididymis. Acta physiol. latinoam. 21, 97-99.

Da Silva e Souza, M.C., Gimeno, M.F. \& Gimeno, A.L. (1974) Spontaneous and testosterone-induced motility of isolated guinea-pig cauda epididymis. Experientia 30, 1063-1065.

EINER-JENSEN, N. (1974) Local recirculation of ${ }^{133}$ xenon and ${ }^{85}$ krypton to the testes and the caput epididymidis in rats. J. Reprod. Fert. 37, 55-60.

Gustafsson, B. (1966) Luminal contents of the bovine epididymis under conditions of reduced spermatogenesis, luminal blockage and certain sperm abnormalities. Acta. vet. scand., Suppl. 17, 1-27.

Hib, J. (1976) Effects of autonomic drugs on epididymal contractions. Fert. Steril. 27, 951-956.

Inano, H., Machino, A. \& Tamaoki, B.I. (1969) In vitro metabolism of steroid hormones by cell-free homogenates of epididymides of adult rats. Endocrinology 84, 997-1003.

Martins, T., Valle, J.R. \& Porto A. (1940) Pharmacology in vitro of the human vasa deferentia and epididymis: the question of the endocrine control of the motility of the male accessory genitals. J. Urol. 44, 682-698.

NorberG, K.A., RisLey, P.L. \& UNGerstedT, U. (1967) Adrenergic innervation of the male reproductive ducts in some mammals. II. Effects of vasectomy and castration. Experientia 23, 392-394.

Prasad, M.R.N., Rajalakshmi, M., Gưta, G. \& KARKUN, T. (1973) Control of epididymal function. J. Reprod. Fert., Suppl. 18, 215-222.

Price, D. \& Ortiz, E. (1965) The rôle of fetal androgen in sex differentiation in mammals. In Organogenesis, pp. 629-652. Eds R. L. deHann \& H. Ursprung. Holt, Rinehart and Winston, New York.

RESKo, J.A. (1970) Androgens in systemic plasma of male guinea pigs during development and after castration in adulthood. Endocrinology 86, 1444 1447.

Risley, P.L. (1959) Hormone effects of the in vivo contractile behaviour of the ductus epididymidis of the rat. Anat. Rec. 133, 329-330.

Risley, P.L. (1961) Effects of castration and testosterone on cholinesterase distributions in the rat epididymis and vas deferens. Anat. Rec. 139, 268.

Risley, P.L. (1963) Physiology of the male accessory organs. In Mechanisms Concerned with Conception, pp. 73-133. Ed. C. G. Hartman. Pergamon Press, London and Oxford.

Setchell, B.P. (1970) Testicular blood supply, lymphatic drainage, and secretion of fluid. In The Testis, Vol. 1, pp. 101-239. Eds A. D. Johnson, W. R. Gomes \& N. L. VanDemark. Academic Press, New York.

TURner, P.C. \& Johnson, A.V. (1971) Epididymal lipid of the rat with and without testicular contribution. J. Reprod. Fert. 27, 249-255.

Received 20 October 1976 